\title{
PENGUATAN ASPEK MANAJEMEN PRODUKSI DAN KUALITAS TEMPE PADA UKM TEMPE
}

\section{STRENGTHENING OF PRODUCTION MANAGEMENT AND TEMPE QUALITY IN UKM TEMPE}

\author{
Dana Marsetiya Utama \\ Jurusan Teknik Industri, Fakultas Teknik, Universitas Muhammadiyah Malang \\ J1. Raya Tlogomas 246, 65144 Malang, Jawa Timur, Indonesia \\ E-mail: dana@umm.ac.id
}

\begin{abstract}
ABSTRAK
Kegiatan ini dilaksanakan di Kelurahan Bakalankrajan Kecamatan Sukun Kota Malang. Mitra dari kegiatan PKM ini adalah UKM tempe "Londho". Masalah yang terjadi di mitra adalah usaha belum membuat standart prosedur produksi yang jelas. Sehingga terkadang kualitas tempe tidak terjaga. Kegiatan ini bertujuan meningkatkan manajemen produksi dan kualitas usaha pada industri tempe di Kelurahan Bakalankrajan Kecamatan Sukun Kota Malang. Metode pelaksanaan kegiatan ini melalui Participatory Rural Apprasial (PRA). Pelaksanaan kegiatan dilakukan dengan pelatihan dan pendampingan manajemen produksi dan kualitas usaha pada industri tempe. Pelatihan diberikan kepada 10 peserta. Materi yang disampaikan pada kegiatan tersebut adalah memberikan gambaran tahapan proses produksi yang baik dan lama proses perebusan kedelai untuk mendapatkan kualitas tempe yang baik.Kesuksesan PKM diukurmelalui peningkatan pengetahuan mitra tentang manajemen produksi dan kualitas usaha pada industri tempe. Hasil pelatihan tersebut menunjukan peningkatan kuantitas produksi, pengetahuan dan keterampilan manajemen produksi dan kualitas usaha industri tempe. Hasil ini menunjukan program PKM efektif untuk meningkatkan kuantitas produksi serta manajemen keuangan usaha.
\end{abstract}

Kata kunci : Manajemen Produksi, Kualitas, Tempe

\section{ABSTRACT}

The activity is conducted in Bakalankrajan Village, Sukun District, Malang City. The partners of this activity are UKM Tempe Londho. The problem that occurs in partners is that the business has not made clear standard production procedures. So that sometimes the quality of Tempe is not fitted. This activity aims to improve production management and business quality in the Tempe industry in Bakalankrajan Village, Sukun District, Malang City. Method of implementing activities through Participatory Rural Appraisal (PRA). The implementation of PKM activities is carried out with training and assistance in production management and business quality in the Tempe industry. Training is given to 10 participants. The material presented at the activity was to provide a description of the stages of the production process which is good, and the process of boiling soybeans is long to get good quality tempeh. PKM's success was measured by increasing partner knowledge about production management and business quality in the Tempe industry. The result of the training shows an increase in the quantity of production, knowledge, and skills of production management and the quality of the Tempe industry business. These results indicate an effective PKM program to increase production quantity and business financial management.

Keywords: Production Management, Quality, Tempe 


\section{PENDAHULUAN}

Tempe adalah makanan tradisional dengan protein tinggi (Shurtleff and Aoyagi, 1979). Tempe merupakan salah satu produk fermentasi berbahan baku kedelai dan mempunyai nilai gizi yang baik.Sebagai makanan tradisional,tempe sangat dikenal masyarakat Indonesia maupun luar negeri. Kualitas protein tempe cukup baik, yang terbukti dari nilai PER (Protein Efficiency Ratio) adalah sebesar 2,43, nilai PER standar (kasein) adalah 2,50 (Murdiati et al., 2000, Palupi and Puspitasari, 1994).Tempe dihasilkan jamur rhizopus oligosporus yang fermentasi dengan bahan kacangkacangan(Haliza et al., 2016).Fermentasi dilakukan dengan mencampur kacangkacangan dengan ragi tempe (rhizopus oligosporus). Kacang kedelai memiliki kandungan proteinnabati yang baik (Ginting et al., 2009).Tempe mengandung senyawa antibakteri yang diproduksi oleh kapang tempe selama proses fermentasi (Koswara, 1995).Padatan putih dihasilkan dari fermentasi tersebut. Miselia jamur yang tumbuhpada permukaan biji kacangkacangan menyebabkan warna putih pada tempe (Halifah, 2011). Gizi yang terkandung dalam tempeadalah vitamin, mineral, serat, lemak, dankarbohidrat(Utari, 2010). Tempe merupakan sumber protein yang baik. Setiap $100 \mathrm{~g}$ tempe mengandung $18-20 \mathrm{~g}$ zat protein dan $4 \mathrm{~g}$ zat lemak (Tarwotjo, 1998).

Home industry tempe "Londho" di Kelurahan Bakalankrajan sukun malang. Pada aspek manajemem pemasaranya, home Industry "Londho" masih mengandalkan proses pemasaran dari mulut ke mulut dan berusaha menjemput pelanggan (karyawa menawarkan produk tempe keliling ke masyarakat). Namun, seringkali usaha tidak bisa memenuhi pesanan dari pelanggan tetap (pedagang sayur keliling dan pedagang pasar). Ketidak mampuan memenuhi pesanan dari pelanggan tetap disebabkan manajemen produksi usaha yang tidak baik. Pada aspek manajemen kualitas, usaha belum membuat standart prosedur produksi yang jelas. Sehingga terkadang kualitas tempe tidak terjaga. Meskipun usaha ini masih bersifat mikro, namun pemilik usaha ini tetap optimis dalam menjalankan usahanya terbukti dengan keinginan kuat untuk mengembangkan usaha dengan meningkatkan kuantitas produksi, memperbaiki proses pengolahan untuk meningkatkan kualitas, memperbaiki manajemen usaha dan memperluas pemasaran produk.

Pada aspek produksi tempe, tahap 1 proses produksi tempe kedelai dan kacang dimulai dengan melakukan pencucian bahan baku kacang dan kedelai. Tahap 2 diilakukan perendaman kedelai dan kacang selama 12 jam, kemudian dilanjutkan perebusan selama 4-5 jam. Tahap 3 melakukan pemecahan kedelai dan kacang serta pemisahan kulit ari dengan menggunakan mesin pemecah. Tahap 4 melakukan pembilasan kedelai hasil pemecahan dengan mesin pemecah agar kedelai dan kacang bersih tanpa kulit ari. Tahap 5 melakukan penirisan kedelai selama 6 jam. Tahap 6 melakukan peragian ke kedelai dan kacang. Tahap 7 proses fermentasi tempe dengan cara menempatkan kedelai dan kacang hasil peragian ke rak selama 24 jam.

Mitra seringkali tidak bisa memenuhi permintaan dari konsumen diarenakan produksi tidak dapat dilakukan secara efisien. Mitra belum berani untuk menambah kapasitas produksi tempe. Hal ini disebabkan proses pembuatan tempe dari bahan baku kedelai dan kacang sampai menjadi tempe diperlukan waktu 2 hari. 
Produk tempe yang dibuat masih menggunakan metode pengolahan yang manual. Proses perebusan kedelai dan kacang menggunakan alat perebusan manual. Proses perebusan kedelai dan kacang membutuhkan waktu 4-5 jam apabila kedelai direndam selama 12 jam. Namun, apabila kedelai dan kacang tanpa dilakukan perendaman membutuhkan waktu perebusan selama 5-6 jam. Kapasitas alat perebusan mitra sebesar 100 $\mathrm{kg}$. Mitra melakukan proses perebusan kedelai dan kacang sebanyak 2 kali perebusan. Total waktu yang diperlukan mitra untuk melakukan proses perebusan kedelai dan kacang 8-9 jam jam per hari. Umumnya permasalahan usaha adalah dibidang penjadwalan produksi (Harto et al., 2016, Nasution et al., 2017, Utama, 2017a), pengendalian persediaan(Utama, 2016, Utama, 2017b, Utama, 2017c), sistem informasi (Utama and Yulianto, 2014, Garside and Utama, 2017, Utama, 2019), kualitas (Utama and Baroto, 2018). Namun, berdasarkan prioritas permasalahan yang telah disepakati antara mitra dan tim PKM maka solusi yang di tawarkan yang akan dicapai melalui program PKM ini adalah memberikan bantuan Pelatihan dan pendampingan Manajemen Produksi dan Kualitas. Pelatihan bertujuan agar mitra manajemen produksi dan kualitas yang baik.

\section{METODE}

Metode kegiatan Program Kemitraan Masyarakat (PKM) dapat dikategorikan menjadi beberapa tahap sebagai berikut: (1) Metode kegiatan yang di laksanakan dengan melakukan Focus Group Discussion (FGD) yaitu melakukan diskusi dengan mitra. FGD digunakan untuk mengidentifikasi masalah mitra, menentukan prioritas masalah, dan memberikan solusi yang tepat bagi mitra. Sedangkan metode Participatory Rural Apprasial (PRA) yaitu melibatkan mitra dalam kegiatan. Pelaksanaan kegiatan ini melalui penyuluhan, pelatihan dan pendampingan serta evaluasi untuk melihat efektifitas program sehingga program tersebut akan berjalan dengan efektif.

Pelaksanaan kegiatan pelatihan dan pendampingan manajemen produksi dan kualitas usaha adalah memberikan gambaran tahapan proses produksi yang baik dan lama proses perebusan kedelai untuk mendapatkan kualitas tempe yang baik. Setelah dan sebelum pelatihan, tim menyebarkan angket ke 10 responden yaang mengikuti pelatihan untuk mengukur pengetahuan responden. Kegiatan Pendampingan dalam mengelola produksi dan kualitas mitra selama 2 bulan dengan memberikan konsultasi kapanpun jika mereka membutuhkan masukan dan mengalami masalah serta kunjungan secara periodik. Selama pendampingan, tim pengabdian akan memonitor omzet penjualan mitra untuk memastikan keberhasilan kegiatan pengabdian ini.

Pertisipasi mitra adalah mengikuti semua kegiatan peyuluhan, pendampingan dan pelatihan yang dilakukan oleh tim PKM serta memberikan kesempatan kepada yang terlibat didalam proses produksi yang dilakukan oleh mitra untuk mengikuti pelatihan serta dapat mengimplementasikan hasil kegiatan.Selanjutnya pengendalian program pengabdian dilakukan melalui kegiatan monitoring, pengawasan, evaluasi, pelaporan dan tindak lanjut terhadap pelaksanaan kegiatan. Pengendalian terhadap seluruh program ditujukan untuk:Memastikan seluruh tahapan kegiatan sesuai dengan program yang telah ditetapkan dan solusi yang ditawarkan ke mitra. Selain itu, Mengendalikan kegiatan agar sesuai dengan program yang telah ditetapkan. Menjaga kualitas kegiatan sehingga dapat memenuhi indikator keberhasilan program yang diamati secara langsung dari 
output (luaran) yang telah diuraikan sebelumnya.

\section{HASIL DAN PEMBAHASAN}

\section{Uji Kualitas Lama Perebusan Kedelai} Pengabdi melakukan percobaan untuk mengetahui kualitas perebusan kedelai produksi tempe. Penentuan kriteria yang digunakan untuk uji kualitas organoleptik selanjutnya melakukan Focus Group Discussion (FGD). FGD dilakukan oleh 2 orang (1 pengusaha dan 1 tim pengabdi). Hasil perhitungan AHP untuk mencari bobot kriteria dapat dilihat pada tabel 1. Perhitungan AHP dilakukan dengan bantuan software expert choice 11 .

Tabel 1 Bobot dan rangking kriteria uji organoleptik berdasarkan AHP

\begin{tabular}{|c|c|c|}
\hline $\begin{array}{ll}\begin{array}{l}\text { kriteria } \\
\text { organoleptik }\end{array} & \text { uji } \\
\end{array}$ & Bobot & Rangking \\
\hline Warna & 0,066 & 5 \\
\hline Rasa & 0,504 & 1 \\
\hline Tekstur & 0,179 & 2 \\
\hline Aroma & 0,179 & 3 \\
\hline Bentuk & 0,072 & 4 \\
\hline \multicolumn{3}{|c|}{ Konsistensi Rasio $=0,00614$} \\
\hline
\end{tabular}

Tabel 2. Hasil perangkingan alternatif lama perebusan terhadap kualitas uji organoleptik

\begin{tabular}{ccc}
\hline Rangking & $\begin{array}{c}\text { Alternatif Lama } \\
\text { Perebusan }\end{array}$ & $\mathrm{Vi}$ \\
\hline 1 & 4 Jam & 0,992 \\
2 & $5 \mathrm{Jam}$ & 0,524 \\
\hline
\end{tabular}

Tabel 2 menunjukan bobot untuk kriteria uji organoleptik berdasarkan AHP dari rangking tertinggi ke terendahadalahRasa mempunyai bobot tertinggi dengan bobot 0,504. Tekstur dengan bobot 0,179. Ketiga yaitu Aroma dengan bobot 0,179. Keempat yaitu Bentuk dengan bobot 0,072. Dan Warna dengan bobot 0,066 . Rasa mempunyai bobot yang paling tinggi. Hal ini menunjukan bahwa rasa menjadi faktor paling penting dalam uji organoleptik.

Rasa mempunyai bobot kriteria paling tinggi karena menjadi faktor utama konsumen dalam memilih makanan. Semakin baik rasa dari makanan, maka kecenderungan konsumen untuk memilih/membeli makanan semakin besar. Sehingga rasa menjadi faktor paling penting sesuai dengan penelitian yang dilakukan oleh Mulyadi et al. (2014). Sedangkan bentuk menjadi kriteria yang kurang di pentingkan dari uji organoleptik. Hal ini disebabkan karena bentuk kedelai akan mengalami transformasi ke bentuk tempe. Ketika kedelai dilakukan fermentasi, bentuk tidak lagi menjadi faktor yang dipentingkan oleh konsumen/pelanggan. Bentuk berkontribusi kecil terhadap preferensi konsumen/pelanggan untuk memilih produk. Sehingga bentuk kurang di pentingkan dalam uji kualitas organoleptik (Astuti, 2009).

Tabel 3 menunjukan hasil pengolahan data dengan metode SAW yang didapatkan hasil akhir rangking untuk tiap alternatif lama perebusan. Berdasarkan tingkat preferensi alternatif lama perebusanterhadap kualitas uji organoleptik didapatkan hasil akir rangking untuk tiap alternatif lama perebusan pertama didapatkan 4 Jam dengan total preferensi 0.992. Rangking kedua adalah alternatif lama perebusan 5 jam dengan total preferensi 0,0524. Hasil ini menunjukan semakin lama proses perebusan menunjukan kualitas organoleptik semakin buruk.

Hasil tersebut menunjukan
semakin lama proses perebusan menunjukan kualitas organoleptik semakin buruk. Hal ini sesuai dengan penelitian yang dilakukan oleh Halifah (2011) dan Dwi Saputri and Arum (2009). Penggunaan teknik AHP dan SAW efisien digunakan 
untuk pemilihan waktu perebusan kedelai dalam produksi tempe. Penggunaan teknik AHP dan SAW lebih efisien karena menggunakan tingkat preferensi pada tiaptiap kriteria dan alternatif

\section{Pelatihan Manajemen produksi dan kualitas}

Pelatihan manajemen keuangan usaha dihadiri oleh 10 peserta. Peserta ini terdiri dari 10 peserta berasal dari tenaga kerja dan pemilik industri. Evaluasi keberhasilan pelatihan dilakukan dengan uji pengetahuan dan uji keterampilan. Uji dilakukan untuk menganalisis signifikansi perubahan pengetahuan sebelum dan sesudah pelatihan. Keterampilan yang berkaitan dengan 1) manajemen produksi tempe yang baik, dan 2) manajemen proses perebusan kedelai agar mendapatkan kualitas tempe yang baik. Ceklis keterampilan digunakan sebagai pedoman penilaian. Setelah pelatihan usai kemudian dilakukan uji keterampilan melakukan manajemen produksi tempe yang baik, dan manajemen proses perebusan kedelai agar mendapatkan kualitas tempe yang baik. Pengetahuan peserta pelatihan meningkat secara signifikan $(\mathrm{p}=0,000)$. Hal itu dapat dilihat dari perubahan nilai rata-rata ketika menjawab soal 1) manajemen produksi tempe yang baik, dan 2) manajemen proses perebusan kedelai agar mendapatkan kualitas tempe yang baik. Hasil uji Wilcoxon dapat dilihat pada Tabel 3.Berdasarkan hasil pelatihan dan pendampingan ini, mitra pengabdian dapat meningkatkan kuantitas produksi. Data produksi dalam 1 minggu dapat dilihat pada gambar 4 .
Tabel 3. Hasil Uji Wilcoxon Pengetahuan peserta pelatihan

\begin{tabular}{lcrrrr}
\hline $\begin{array}{l}\text { Pengeta } \\
\text { huan }\end{array}$ & N & Mean & $\begin{array}{r}\text { Std. } \\
\text { Deviat } \\
\text { ion }\end{array}$ & Z & $\begin{array}{r}\text { Asymp. } \\
\text { Sig. } \\
\text { (2-tailed) }\end{array}$ \\
\hline Sebelum & 10 & $\begin{array}{r}12,56 \\
50\end{array}$ & $\begin{array}{r}2,642 \\
08\end{array}$ & $\begin{array}{r}2,72 \\
5^{\text {b }}\end{array}$ & 0,000 \\
\hline Sesudah & 10 & 22,42 & 1,125 & & \\
& & 50 & 99 & & \\
\hline
\end{tabular}



Gambar 4. Data produksi mitra setelah pelatihan dan pendampingan

Kegiatan pelatihan dimulai dengan diskusi dengan industri tempe dengan topik proses produksi dan kualitas tempe. Pada pelatihan ini, tim pengabdi meyakinkan industri tempe tentang manfaat proses produksi dan manajemen kualitas di UKM. Apabila manajemenproduksi dan kualitas dilaksanakan dengan baik, maka akan memberikan manfaat langsung bagi kelangsungan usaha.

Hasil yang dicapai dari kegiatan pelatihan ini menunjukkan terdapatpeningkatan pengetahuan dari peserta pelatihan (Tabel 3). Kegiatan pelatihan merupakan salah satu media untukmenyampaikan informasi yang efektif (Prasanti and Fuady, 2017). Selain itu, metodepelatihan dan pendampingan memberikan pengaruh secara sigfinikan terhadap tingkat pengetahuan dandengan pengetahuan yang dimiliki dapatditerapkan dalam kehidupan sehari-hari(Anggoro et al., 2018)termasuk penerapan dalam 
mencapai kualitas produksi tempe yang baik.

Setelah kegiatan pelatihan dilanjutkan denganpraktek produksi dan manajemen kualitas tempe.Sebelum pelatihan dilakukan, pada umumnya usaha tidak menggunakan standart waktu perebusan dalam kedelai. Tim pengabdi telah malakukan studi lama proses perebusan untuk meningkatkan kualitas tempe. Hasil penelitian menunjukan lama proses perebusan kedelai yang ideal adalah 4 jam. Hasil pelatihan ini, industri menggunakanlama proses perebusan kedelai yang ideal selama 4 jam. Padakegiatan ini, para peserta aktif berinteraksi dengan tim pengabdi.

Kegiatan telah dilakukan dengan hasil terlihat dapatmeningkatkan manajemem proses produksi dan kualitas tempe. Hal ini ditunjukkan dengan mitra terlibat dalam semua kegiatan. Pengetahuan mitra tentang manajemem proses produksi dan kualitas tempe setelah pelatihan dan pendampingan meningkat. Mitra menyadari bahwa manajemem proses produksi dan kualitas tempe sangat penting bagi industri tempe.

Kegiatan ini adalah suatu upaya untuk memperkuat dan mengembangkanpotensi yang dimiliki oleh mitra (Minarni et al., 2017). Untuk mengetahui tingkat keberhasilan daripelaksanaan program pengabdian masyarakatini maka perlu dilakukan pemantauan danevaluasi. Pemantauan dilakukan selamapelaksanaan hingga selesai kegiatan dandilanjutkan dengan evaluasi kegiatan. Metodeyang digunakan untuk mengetahuikeberhasilan kegiatan penyuluhan adalahdengan mengukur tingkat pengetahuan tentang manajemen produksi dan kualitas produksi tempe.

Untuk melihat dampak nyata darikegiatan program PKM ini dilakukanevaluasi kegiatan yang telah dilaksanakan.Sistem evaluasi yang dilakukan pada kegiatanini adalah dengan turun meninjau ke industri.Tim pengabdi mengunjungi industri tempe untuk melihat hasil pelatihan dan pendampingan yang diberikan. Hasil evaluasi menunjukkan bahwa industri telah menerapkan manajemen produksi dan kualitas tempe

\section{SIMPULAN}

Dari kegiatan yang sudah dilakukan menunjukan bahwa kegiatan pengabdian dapat memberikan dampak yang cukup signifikan kepada mitra. Namun, tim PKM perlu melakukan kegiatan lebih lanjut untuk memastikan mitra dapat memperbaiki kegiatan produksi dan manajemen.

\section{UCAPAN TERIMA KASIH}

Ucapan terimakasih kepada Universitas Muhammadiyah Malang yang memberikan dukungan dalam pelaksanaan Program Kemitraan Masyarakat

\section{DAFTAR PUSTAKA}

Anggoro, S., Harmianto, S. \& Yuwono, P. D. (2018). Upaya Meningkatkan Kemampuan Pedagogik Guru Melalui Pelatihan Pembelajaran Tematik Sains Menggunakan Inquiry Learning Process dan Science Activity Based Daily Life. JPPM (Jurnal Pengabdian dan Pemberdayaan Masyarakat), 2, 29-35.

Astuti, N. P. (2009). Sifat Organoleptik Tempe Kedelai yang Dibungkus Plastik, Daun Pisang dan Daun Jati. Universitas Muhammadiyah Surakarta.

Dwi Saputri, S. \& Arum, K. (2009). Pengaruh lama pemasakan dan temperatur pemasakan kedelai terhadap proses ekstraksi protein kedelai untuk pembuatan tahu. 
Garside, A. K. \& Utama, D. M. (2017). Perancangan Sistem Informasi Laboratorium Teknik Industri Universitas Muhammadiyah Malang. Research Report, 1.

Ginting, E., Antarlina, S. S. \& Widowati, S. (2009). Varietas unggul kedelai untuk bahan baku industri pangan. Jurnal Litbang Pertanian, 28, 7987.

Halifah, P. (2011). Pengaruh lama perebusan terhadap kadar protein tempe kacang tunggak (Vigna unguiculata). bionature, 12.

Haliza, W., Purwani, E. Y. \& Thahir, R. (2016). Pemanfaatan kacangkacangan lokal sebagai substitusi bahan baku tempe dan tahu. Buletin Teknologi Pasca Panen, 3, $1-8$.

Harto, S., Garside, A. K. \& Utama, D. M. (2016). Penjadwalan Produksi Menggunakan Algoritma Jadwal Non Delay untuk Meminimalkan Makespan Studi Kasus Di CV. Bima Mebel. Spektrum Industri, 14.

Koswara, S. (1995). Teknologi pengolahan kedelai, Jakarta, Pustaka Sinar Harapan.

Minarni, E. W., Utami, D. S. \& Prihatiningsih, N. (2017). Pemberdayaan Kelompok Wanita Tani Melalui Optimalisasi Pemanfaatan Pekarangan dengan Budidaya Sayuran Organik Dataran Rendah Berbasis Kearifan Lokal dan Berkelanjutan. JPPM (Jurnal Pengabdian dan Pemberdayaan Masyarakat), 1, 147-154.

Mulyadi, A. F., Wijana, S., Dewi, I. A. \& Putri, W. I. (2014). Karakteristik organoleptik produk mie kering ubi jalar kuning (Ipomoea batatas)(kajian penambahan telur dan CMC). Malang: Fakultas Teknologi Pertanian. Universitas Brawijaya.

Murdiati, A., Sardjono, S. \& Amaliah, A. (2000). Perubahan Komposisi Kimia Tempe Gembus yang Dibuat dari Bahan Dasar Ampas Tahu Ditambah Bekatul (The Different of Chemical Composition of Tempe Gembus Produced by Addition of Rice Bran to The Raw Material). Agritech, 20, 106-110.

Nasution, R., Garside, A. K. \& Utama, D. M. (2017). Penjadwalan Job Shop Dengan Pendekatan Algoritma Artificial Immune System. Jurnal Teknik Industri, 18, 29-42.

Palupi, N. \& Puspitasari, N. L. (1994). Pengaruh serat makanan dan senyawa antinutrisi dalam tempe terhadap ketersediaan mineral bagi tubuh. Laporan Penelitian. Bogor: Fakultas Teknologi Pertanian, Institut Pertanian Bogor.

Prasanti, D. \& Fuady, I. (2017). Penyuluhan Program Literasi Informasi Kesehatan Dalam Meningkatkan Kualitas Sanitasi Bagi Masyarakat Di Kaki Gunung Burangrang Kab. Bandung Barat. JPPM (Jurnal Pengabdian dan Pemberdayaan Masyarakat), 1, 129-138.

Shurtleff, W. \& Aoyagi, A. (1979). The book of tempe, a super soyfood from Indonesia. Harper \& Row. New York.

Tarwotjo, C. S. (1998). Dasar-Dasar Gizi Kuliner, Jakarta, Gramedia Widiasarana Indonesia.

Utama, D. M. (2016). Penentuan Lot Size Pemesanan Bahan Baku Dengan 
Batasan Kapasitas Gudang. Jurnal Ilmiah Teknik Industri, 15, 64-68.

Utama, D. M. (2017)a. Analisa Perbandingan Penggunaan Aturan Prioritas Penjadwalan Pada Penjadwalan Non Delay N Job 5 Machine. Research Report, 1.

Utama, D. M. (2017)b. Model Penentuan Lot Pemesanan Dengan Mempertimbangkan Unit Diskon dan Batasan Kapasitas Gudang dengan Program Dinamis. Jurnal Teknik Industri, 18, 94-102.

Utama, D. M. (2017), Model Program Dinamis Dalam Penentuan Lot Pemesanan dengan Mempertimbangkan Batasan Modal. Prosiding, SENTRA (Seminar Teknologi dan Rekayasa),

Utama, D. M. (2019). Pengembangan Algoritma NEH Dan CDS Untuk Meminimasi Consumption Energy Pada Penjadwalan Flow Shop. 2019, 8.

Utama, D. M. \& Baroto, T. 2018. Penggunaan SAW Untuk Analisis Proses Perebusan Kedelai Dalam Produksi Tempe. AGROINTEK, 12, 90-98.

Utama, D. M. \& Yulianto, F. 2014. Perancangan Sistem Enterprise Resource Planning Modul Sales Pada Distributor Beras Ud Manis. Jurnal Teknik Industri, 15, 61-69.

Utari, D. M. 2010. Kandungan Asam Lemak, Zink, Dan Copper Pada Tempe, Bagaimana Potensinya Untuk Mencegah Penyakit Degeneratif. Gizi Indonesia, 33. 